\title{
Groundwater Quality Determination from Hand-Dug Wells in Ososo Town, Akoko-Edo North Local Government Area Edo State
}

\author{
E. G. Maju-Oyovwikowhe*, W. O. Emofurieta* \\ Department of Geology, University of Benin, Benin City, Edo State, NIGERIA.
}

\begin{abstract}
Groundwater is water beneath the surface of the earth. The primary source is precipitation from rain, snow, and hail. Groundwater commonly occurs as water that fills pore spaces between mineral or rock grains in sediments and sedimentary rocks. This study is to evaluate the physiochemical characteristics and selected heavy metal levels of Water from Hand Dug Wells in Ososo in Akoko Edo Local Government Area of Edo State, Nigeria. A total of twenty (20) water samples were collected in very clean containers from twenty (20) hand dug wells in Ososo town, and taken to the laboratory immediately for physical, chemical and heavy metal analysis using standard laboratory techniques. The physical analysis results from the study show that depth to ground water is very shallow. Ph was below 7.5. Conductivity varies from 167.8-2120.00 / cm. The temperatures were uniform. The ground water is odorless and tasteless. The amounts of total suspended soil (TSS) in all the samples vary from 10-20 ppm. The total dissolved solid content (TDS) concentration for all the samples varies from 132-1320.00 ppm. Total hardness is soft to moderately hard. Total alkalinity values vary between 3.0 to $18.0 \mathrm{ppm}$. The phenolphthalein value for the sample tested was zero. Chemical analysis results for the cations shows that Calcium (Ca) is one of the most abundant cations in the entire well water samples with concentration varying from $6.4-40.0 \mathrm{mg} / \mathrm{L}$. Magnesium (Mg) concentration vary from $2.0-9.5 \mathrm{ppm}$. Dissolved Sodium (Na) content values vary from $17.9-92.5 \mathrm{mg} / \mathrm{L}$. Chemical analysis results for the anions shows that the concentration of sulphate $\left(\mathrm{SO}_{4}\right)$ ions varies from 93-125 $\mathrm{mg} / \mathrm{L}$. The bicarbonate $\left(\mathrm{CO}_{3}\right)$ concentration in all samples varies from $25.7-90 \mathrm{mg} / \mathrm{L}$. The dissolved nitrites and nitrates concentrations varies from 5.7 - 9.1. Heavy metals analysis shows the concentrations of copper (CU) in the samples range from $0.1-0.5 \mathrm{mg} / \mathrm{l}$. The result of the analysis indicates high values of lead $(\mathrm{Pb})$ in nine samples, but lead was not detected in wells 6 and 7. The values for other wells ranged between 0.1-0.2 mg/l. The values for the concentration of chromium (Cr)range from $0.4-0.89 \mathrm{mg} / \mathrm{l}$. The values of barium (Ba) range from 0.05$0.3 \mathrm{mg} / \mathrm{l}$. Result from the heavy mineral analysis for Cadmium (Cd) gave an approximate value of 0.2 and below detectable limit in the other wells. The values of $Z$ inc $(\mathrm{Zn})$ range from $0.8-11.4 \mathrm{mg} / \mathrm{l}$. The values of Nickel (Ni) range from 0.1-0.5 $\mathrm{mg} / \mathrm{l}$.The hand-dug wells in the study area contain free Carbon IV Oxide and the alkalinity of the well water is entirely due to Bicarbonate ions. Sodium, chloride, bicarbonates, calcium, iron, potassium and magnesium are the most abundant. All the dissolved anions in the well water sample are generally below the recommended maximum limits by WHO.Samples also showed high bacteria load which primarily originated from effluent discharge from pit toilets and waste dumps and can constitute health risk on ingestion. Highly populated areas have groundwater with high concentration of dissolved ions and the converse for areas of low population. From the results of the analysis, conclusion is drawn to the fact that, the groundwater chemistry in the study area has been influenced greatly by human activities than the bedrock geology of the area. It is therefore recommended that well location should be at least, $30 \mathrm{~m}$ away from any source of contamination such as soakways, adequate treatment must be given to well water such as chlorination, boiling to destroy any bacteria and filtration to remove all unwanted / undesirable constituents that may be present, and a policy on land use planning and urban development to guard against indiscriminate setting of wells within the centre of the village should be established. This study has been able to enhance sustainable water development, since the health of inhabitants in a community depends to a large extent on the quality of groundwater supply.
\end{abstract}

Keywords: groundwater quality, physiochemical, heavy metals, Ososo town

* Corresponding author (Tel: +234(0) 810704 0751)

Email addresses: efetobore.maju@uniben.edu (E.
G. Maju-Oyovwikowhe), emof.william@gmail.com (W. O. Emofurieta) 


\section{INTRODUCTION}

Water is one of the basic necessities of human life. Humans can live without food for 40 days but cannot survive without water for 3 days. Water is crucial for human life and development. The demand of freshwater for agriculture,industrial and domestic use is very high. As human population increases the demand for potable water also increases. The availability of water for domestic use in many parts of Nigeria depends largely on harnessing of shallow hand -dug wells which are peculiar to many towns in the Southwestern Nigeria.Some of these towns are Akure, Ilesha, Igarra and Ososo, where the weathered and fractured crystalline rocks of the basement complex constitute shallow aquifers. Groundwater is one of the reservoirs of the hydrologic cycle, groundwater is freshwater located in the pore spaces of soils and rocks, and it is also water that flows within aquifers below the water Table. The hydrologic cycle describes the continuous movement of water above on and below the surface of the earth. The study of groundwater occurrence and its movement has become very important in view of acute shortage of pipe borne water supply and surface water. The ratio of surface water to groundwater was put at 1:3 [1]. Sources of groundwater are meteoric water that infiltrates the ground and moves through the pores of rocks and soils. Other source of groundwater includes water infiltrating from lakes and streams. As rain water percolates through soil, sediments and rocks, it leaches impurities from the surrounding bedrocks into the groundwater reservoir. According to Onyeobi and Akujieze [2], Akpoborie [3] and Oteze [4], the stratigraphy of a terrain plays an important role in groundwater contamination especially when the aquifer geometry is unconfined. If an aquifer is unconfined and shallow, there is a high probability of vulnerability to contaminants of whatever source and kind, especially when they are closed to area of high population density with high anthropogenic activities [5]. The quality of water for various purposes depends on the concentration of these substances. The objective of this study is to evaluate the physiochemical characteristics and selected heavy metal levels of Water from Hand Dug Wells in Ososo in Akoko Edo Local Government Area of Edo State, Nigeria, in order to educate the inhabitants of the area on any impending health danger in connection with the domestic use of these waters. The physiochemical factors affecting the groundwater and its suitability for human consumption based on the established standards by the world health organization (W.H.O) and other regulatory bodies has been established in this study.

\section{MATERIALS AND METHODS}

\subsection{Description of Study Area}

The study area lies within the Akoko Edo North Local Government Area of Edo State. It lies between coordinates $07^{\circ} 25^{\prime} \mathrm{N}$ and $06^{\circ} 16^{\prime} \mathrm{E}$. Ososo is one of the largest towns in the Local Government Area. Samples were

\subsection{Geology of the Study Area}

The regional geology of Igarra (Ososo) is dominated by crystalline rocks which forms part of the basement complex of Southwestern Nigeria. The rock in the area includes migmatite, granite charnockite and quartzite with some minor intrusives like quartz veins. The crystalline rocks of the basement complex of this region form triangular shape and lie to the east of the West African craton, the rocks extend westward being continuous with the Dahomeyan of the Benin republicTogo-Ghana. The crystalline basement complex of this region form triangular shape and lie to the east of the West African craton. The basins in the southwestern Nigeria are the Dahomeyan basin, middle Niger basin and the Niger Delta basin. Coorey [6], Rahaman et al. [7], and many other authors have studied the petrographic and lithological classification of the basement complex. Ososo is a scenic town of streams and rocks in the undulating Semorika hills. The town is located in Akoko-Edo local government with an average altitude of $1236 \mathrm{ft}$ a biotite granite gneiss form the metamorphic sequence. The metamorphic sequence was later intruded during the pan African orogeny by a highly zenolitic medium grained biotite granite. The metamorphic rocks are NorthSouth trends and dips at an angle of 500W. The contact relationship is sharp. The quartz biotite schisthas been weathered chemically over the years to form a fairly thick overburden that acts as the aquifer for the hand-dug wells. The rocks of the study area were affected by the pan African Orogeny which occurred between 700-750 $\mathrm{Ma}[8]$.

\subsection{Sampling}

Groundwater samples were collected from twenty (20) hand-dug wells in Ososo metropolis (Fig. 1). The sampled wells where chosen randomly, ensuring their fair distribution over the entire study area. The choice of well depends on its distances from a previously chosen well in the locality, the wish of the owner to make the well available for study, and the observed Geology. Rubber cans which usually give the least contamination ([9]) were used to collect water samples from all the wells studied, and it was ensured that the quantity collected was sufficient for the number of parameters to be investigated. In most cases, 1litre or $250 \mathrm{ml}$ bottle was sufficient and rinsed out with the water samples from the well in each location.

\subsection{Preservation and Treatment}

In order to prevent or reduce change in quality of the water samples, physical parameters like odor, taste, colour and appearance were observed on the field. The Ph, alkalinity, hardness and the analyses of unstable radicals like nitrite, phosphate, silicaand bicarbonate were all carried out shortly after collection of each water sample [3]. The samples were then stored in a refrigerator and the temperature kept below $20^{\circ} \mathrm{C}$. [10]. 


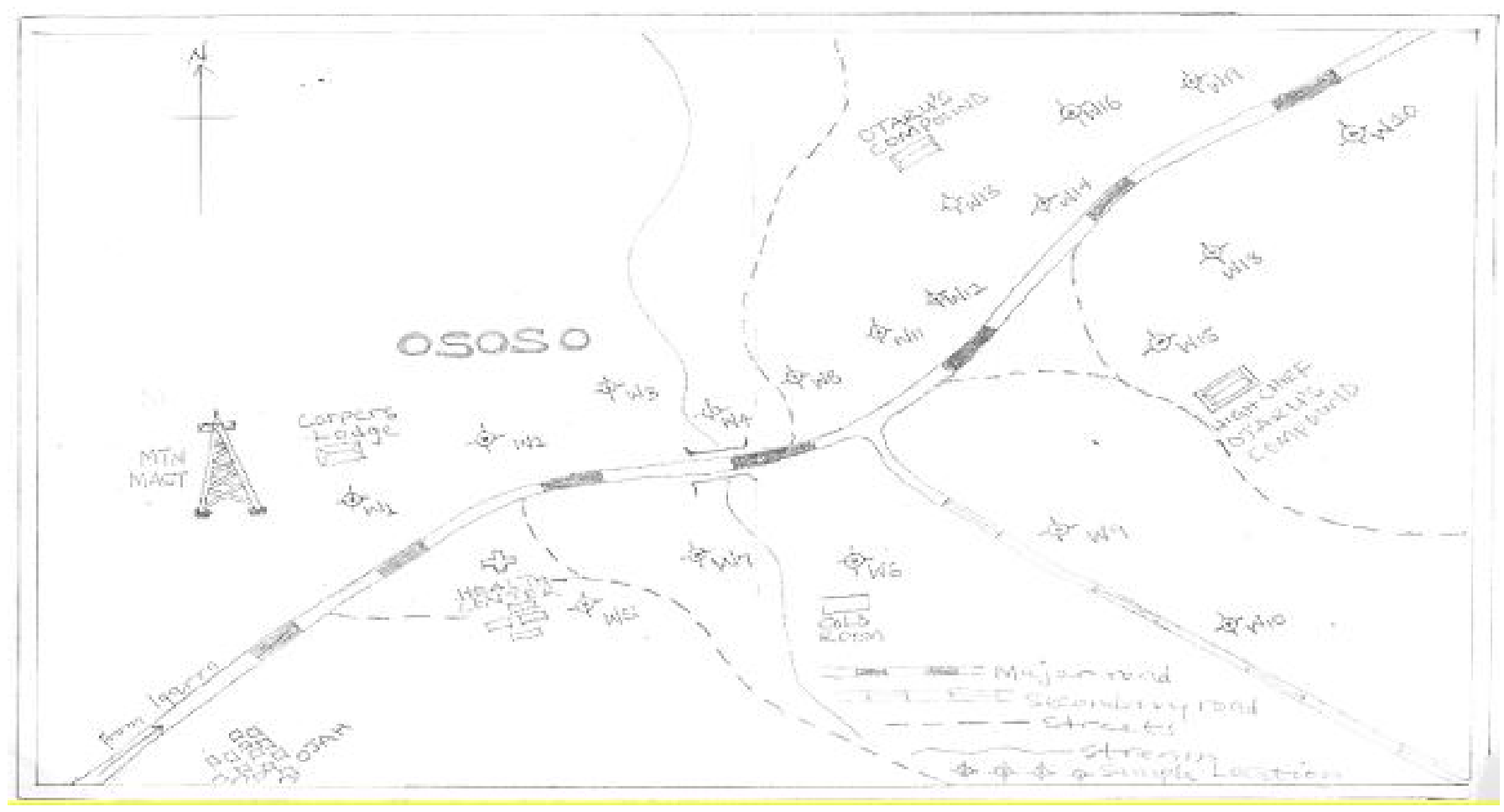

Figure 1: Sketched map of Ososo showing sampled location.

\subsection{Procedures}

\subsubsection{Temperature}

This parameter was determined with a thermometer having a calibration from $-10^{\circ} \mathrm{C}$ to $110^{\circ} \mathrm{C}$

\subsubsection{Colour}

Visual observation of the water sample was used and the result was recorded as either clear or turbid.

\subsubsection{Odour and taste}

Manual sensing of the water samples was adopted.

\subsubsection{Determination of ph}

$\mathrm{Ph}$ is the negative logarithm of the hydrogen ion concentration. It is a method of expressing the acidity and alkalinity of aqueous solution. The solubility of ions in water is strongly influenced by the $\mathrm{pH}$ value of the water.

\subsubsection{Determination of conductivity}

The conductivity was determined directly from the various samples by using conductivity meter. Conductivity is another important criterion in measuring the electrical resistance of a solution, which is to draw information on the total ionic concentration in the solution. The conductance for water is related to the total concentration of dissolved ions, their mobility, and temperature measurement. The purity of water is commonly checked by conductivity meter.

\subsubsection{Total dissolved solids (TDS)}

Apparatus are evaporating dish or beaker, oven, desiccators, steam bath, $100 \mathrm{ml}$-measuring cylinder. $100 \mathrm{ml}$ of the samples was measured and filtered into $100 \mathrm{ml}$ measuring cylinder using a pre weighed filter paper; it was made up to $100 \mathrm{ml}$ with distilled water. It was later, transferred into pre-weighed crucible and evaporated into dryness in steam water bath, dried in an oven at $180^{\circ} \mathrm{C}$ for $11 / 2$ hours, cooled in desiccators and weighed. The weight of the crucible was recorded as W1, with dissolved solid as W2.

\subsubsection{Total suspended solids (TSS)}

This represents the portion of solid retained by a filter. The pre-weighed filter paper used for total dissolved solids was dried at $105^{\circ} \mathrm{C}$ for half hours .It was cooled in desiccators and weighed .The weight of pre-weighed filter paper was W1 and the weight of the paper and residue after drying was $\mathrm{W}_{2}$. Calculation is TSS $(\mathrm{ppm})=\mathrm{W}_{2}-\mathrm{W}_{1}$ × $103 \mathrm{ppm}$.

\subsubsection{Determination of total alkalinity}

The total alkalinity was determined by titration with a standard solution of hydrochloric acid. $50 \mathrm{ml}$ of the water sample was pipette into clean $150 \mathrm{ml}$ capacity conical flask. 3 drops of phenolphthalein indicator was added to check for presence of carbonates and hydroxides alkalinities at the initial stages of the titration. There was no change in colour of the samples. Then 3 drops of methyl orange indicator was added and titrated further until the colour changed from yellow to brick red and the values was recorded to determine the bicarbonate alkalinity. 


\subsubsection{Determination of hardness}

The total hardness was determined by titration with disodium dehydrogenate ethylene diamante tetra-acetate dehydrates (EDTA salt) using Erichrome black T as indicator and a mixture of borax, sodium hydroxide and sodium sulphide as buffer. $50 \mathrm{ml}$ of sample was measured into a $150 \mathrm{ml}$ conical flask, then $10 \mathrm{ml}$ of buffer solution was added, 10 drops of $5 \%$ hydroxyl aminehydrochloric was added and 10 drops of $2 \%$ analytical grade of sodium was the addition of 2 drops of Erichrome black T. The water sample was titrated against EDTA; the end point was observed when the colour changed from purple to blue. The result was expressed in ppm $\left(\mathrm{CaCO}_{3}\right)$. Magnesium hardness was subtracted from the total hardness to obtain the calcium hardness.

\subsubsection{Determination of chloride}

The Mohr's method was employed using silver nitrate as titrate and potassium chromate as the end point indicator the chloride ion present in the water precipitated as white silver chloride. $50 \mathrm{ml}$ of the sample was measured into a conical flask and 10 drops of potassium chromate was then added, which the water samples to yellow. The water samples then titrated against $0.05 \mathrm{ml}$ of silvernitrate the titration endpoint is the change in colour from yellow to reddish brown.

\subsubsection{Determination of sulphate}

Gravimetric method was used to determine sulphate using $\mathrm{Bacl}_{2}$ as precipitant. $50 \mathrm{ml}$ of the sample was measured in a $250 \mathrm{ml}$ beaker, and diluted with $150 \mathrm{ml}$ distilled water. $2 \mathrm{ml}$ conc. (HCL) and 4 drops of methyl orange indicator was added. The samples were placed on hot plate. $10 \mathrm{ml}$ of $10 \% \mathrm{Bacl}_{2}$ solution was measured intoit and then boiled for 5 minutes. The samples were then removed from hot plate and left overnight for filtration. The beakers and the precipitate were washed with hot distilled water until chloride free completely. The samples were put into the furnace at $800^{\circ} \mathrm{C}$ for 1 hour, thereafter cooled in desiccators and weighed.

\subsubsection{Determination of nitrate}

The nitrate concentration was determined by chlorimetric method. This involved using hydrazine sulphate $\left(\mathrm{N}_{2} \mathrm{H}_{2} . \mathrm{H}_{2} \mathrm{SO}_{4}\right)$ and copper sulphate $\left(\mathrm{CuSO}_{4} .5 \mathrm{H}_{2} \mathrm{O}\right)$ was used as catalyst to obtain a reddish colour the intensity of which was then matched with the standard Aqua Merck nitrate colour scale. The corresponding concentration was read in the scale in ppm. The kit has the singular advantage of allowing rapid determination of the ionic concentration on or close to site.Nitrite, silicate and phosphate were determined through similar method above, using the Aqua Merk water analysis reagent kit.

\subsubsection{Determination of metals}

Buck model Flame Atomic absorption spectrophometer (ASS) is similar to flame emission spectrophometer. In (ASS), the samples were aspirated into the flame and atomized. Standard solution was prepared from the solution in ppm for each metal using suitable metal salt of each element to be determined. The instrument was switched on for about 15 minutes to amp up for stability and the required lamp for each metal was fixed. The standard of each metal was aspirated simultaneously as well as the samples serially. The absorbance series was then recorded under the same condition (Buck Scientific Operations Manual book for ASS).

\subsubsection{Determination of coliform levels}

Multiple Tube Fermentation Method- Apparatus used include test tubes, Petri-dish, inoculating lamp, syringe pipette, aluminum foil, test tube track, cotton-wool, slides, matches, microscope, incubator, refrigerator, autoclave, mettle balance.All apparatus to be used were first sterilized using autoclave. Series of dilutions were made up to 10-2 sample test was poured and covered with the Petri-dish. Some portion of the nutrient brought that had been already prepared was added. The mixture was gently and evenly rocked and allowed to gel, it was then incubated for 3 days after which it was transferred to the refrigerator. The water sample was cultured single and double strength Mac Conkey brought in the tubes showing positive result i.e. medium turned yellow or pale yellow and formation of gas in the Durham tubes were further cultured using Eosin methylene blue. Colonies of green metallic sheen or Eosin methylene blue confirmed the presence of E-coli in such sample.

\section{RESULTS AND DISCUSSION}

Result of the physiochemical analysis of the well water samples is presented in Table 1 .

\subsection{Physical Analysis Results}

\subsubsection{Depth of groundwater}

The depth to ground water varies from 2'3' to 8'10'. The shallowness of the ground water is disadvantageous because it renders the groundwater system highly susceptible to contamination by anthropogenesis sources. The wells are roughly shallowest at the middle of the town and get deeper outwards. The groundwater will not have had enough time to percolate through a sizeable soil column that will do the purification of the water before storage in the aquifer.

\subsubsection{Ph (moles per liter)}

The samples tested have below 7.5, varying from 6.65-7.05 (i.e. slightly acidic to slightly alkaline).This implies there were little or no dissolve carbonate and hydroxide ions in the samples. This also indicates the presence of free carbon IV oxide; thus, the dissolved inorganic carbon exists almost entirely as bicarbonate ions

\subsubsection{Conductivity (Siemens per meter $(S / m)$ )}

The conductivity values for all the well water sample tested varies from $167.8-2120.00 / \mathrm{cm}$. About $40 \%$ of the water samples tested were below those of UNIBEN Table water and WHO standard 
Table 1: Result of physiochemical analysis.

\begin{tabular}{|c|c|c|c|c|c|c|c|c|c|c|c|c|c|c|c|c|c|c|c|c|c|}
\hline Parameter & Unit & W1 & W2 & W3 & W4 & W5 & W6 & W7 & W8 & W9 & W10 & W11 & W12 & W13 & W14 & W15 & W16 & W17 & W18 & W19 & UNIBEN \\
\hline Appearance & CLEAR & $\mathrm{C}$ & $\mathrm{C}$ & $\mathrm{C}$ & $\mathrm{C}$ & $\mathrm{C}$ & $\mathrm{C}$ & $\mathrm{C}$ & $\mathrm{C}$ & $\mathrm{C}$ & $\mathrm{C}$ & $\mathrm{C}$ & $\mathrm{C}$ & $\mathrm{C}$ & $\mathrm{C}$ & $\mathrm{C}$ & $\mathrm{C}$ & $\mathrm{C}$ & $\mathrm{C}$ & $\mathrm{C}$ & $\mathrm{C}$ \\
\hline $\begin{array}{l}\text { Depth of } \\
\text { Groundwater }\end{array}$ & (m) & 7.04 & 5.54 & 8.45 & 3.73 & 3.95 & 5.34 & 4.63 & 6.71 & 5.20 & 5.41 & 5.88 & 5.17 & 5.54 & 4.81 & 6.54 & 5.50 & 4.78 & 5.69 & 5.87 & 7.39 \\
\hline Temp $\left({ }^{\circ} \mathrm{C}\right)$ & NS & 28.0 & 28.5 & 28.3 & 27.8 & 28.3 & 28.2 & 28.3 & 27.8 & 28.2 & 27.7 & 27.6 & 28.3 & 28.5 & 27.6 & 28.4 & 28.8 & 28.3 & 27.6 & 28.7 & 27.9 \\
\hline Conductivity & $(\mu \mathrm{s} / \mathrm{cm})$ & 170 & 50 & 180 & 180 & 200 & 180 & 200 & 190 & 180 & 60 & 70 & 40 & 180 & 180 & 170 & 160 & 170 & 180 & 200 & 160 \\
\hline $\mathrm{pH}$ & $\mathrm{Ph}$ & 7.34 & 7.20 & 7.10 & 7.30 & 6.98 & 6.87 & 7.12 & 7.30 & 6.80 & 6.90 & 7.10 & 6.98 & 6.89 & 7.50 & 7.80 & 6.80 & 7.80 & 7.80 & 6.98 & 7.80 \\
\hline Color & Hazen & $<15$ & $<15$ & $<15$ & $<15$ & $<15$ & $<15$ & $<15$ & $<15$ & $<15$ & $<15$ & $<15$ & $<15$ & $<15$ & $<15$ & $<15$ & $<15$ & $<15$ & $<15$ & $<15$ & $<15$ \\
\hline Turbidity & (NTU) & 10.6 & 8.90 & 9.78 & 10.7 & 11.9 & 23.5 & 22.3 & 11.8 & 10.8 & 27.5 & 21.8 & 19.8 & 8.90 & 7.98 & 7.67 & 17.3 & 13.3 & 17.6 & 6.55 & 8.98 \\
\hline Total Hardness & $(\mathrm{mg} / \mathrm{L})$ & 86.7 & 90.0 & 40.6 & 112. & 113. & 40.6 & 120 & 75.0 & 56.0 & 66.0 & 86.0 & 76.0 & 56.0 & 79.0 & 47.0 & 59.0 & 43.9 & 8.00 & 70.6 & 80.4 \\
\hline $\begin{array}{l}\text { Calcium } \\
\text { Hardness }\end{array}$ & $(\mathrm{mg} / \mathrm{L})$ & 68.00 & 48.00 & 38.00 & 20.00 & 20.00 & 19.00 & 20.00 & 22.00 & 40.00 & 50.00 & 80.00 & 52.00 & 36.00 & 16.00 & 19.50 & 20.00 & 18.90 & 114.0 & 112.9 & 70.00 \\
\hline $\begin{array}{l}\text { Magnesium } \\
\text { Hardness }\end{array}$ & $(\mathrm{mg} / \mathrm{L})$ & 20.00 & 19.00 & 24.00 & 17.00 & 48.00 & 16.00 & 10.00 & 15.00 & 16.00 & 68.00 & 41.00 & 18.00 & 31.00 & 11.00 & 12.50 & 13.00 & 16.00 & 40.40 & 50.60 & 60.90 \\
\hline Nitrate $\left(\mathrm{NO}_{32}\right)$ & $(\mathrm{mg} / \mathrm{L})$ & 5.70 & 7.40 & 6.80 & 8.40 & 6.89 & 7.10 & 12.90 & 8.80 & 7.50 & 8.30 & 6.40 & 7.60 & 5.60 & 7.50 & 13.20 & 12.20 & 11.10 & 10.30 & 8.90 & 6.40 \\
\hline Chloride (Cl) & $(\mathrm{mg} / \mathrm{L})$ & 86.90 & 87.88 & 113.0 & 14.62 & 12.70 & 54.76 & 12.70 & 18.90 & 12.50 & 0.014 & 50.78 & 49.40 & 18.30 & 13.50 & 37.00 & 35.90 & 40.80 & 34.78 & 0.013 & 13.90 \\
\hline $\begin{array}{l}\text { Manganese } \\
\left(\mathrm{Mn}^{2+}\right)\end{array}$ & $(\mathrm{mg} / \mathrm{L})$ & 0.013 & 0.009 & 0.024 & 0.017 & 0.023 & 0.033 & 0.034 & 0.018 & 0.025 & 0.014 & 0.015 & 0.014 & 0.019 & 0.018 & 0.023 & 0.017 & 0.025 & 0.029 & 0.008 & 0.009 \\
\hline Odor & Unobj & Unobj & Unobj & Unobj & Unobj & Unobj & Unobj & Unobj & Unobj & Unobj & Unobj & Unobj & Unobj & Unobj & Unobj & Unobj & Unobj & Unobj & Unobj & Unobj & Unobj \\
\hline Total Alkalinity & $(\mathrm{mg} / \mathrm{L})$ & 99.70 & 110.6 & 101.0 & 100.0 & 95.69 & 107.2 & 102.7 & 89.70 & 100.5 & 103.0 & 100.5 & 76.65 & 86.40 & 79.00 & 93.55 & 110.7 & 108.5 & 109.3 & 69.55 & 95.00 \\
\hline Sulphate $\left(\mathrm{S}_{4}^{2-}\right)$ & $(\mathrm{mg} / \mathrm{L})$ & 119.8 & 105.7 & 108.5 & 109.7 & 112.7 & 114.7 & 98.99 & 101.0 & 104.3 & 100.8 & 110.5 & 120.0 & 115.6 & 125.5 & 85.99 & 99.95 & 119.5 & 99.30 & 100.0 & 99.79 \\
\hline Iron $\left(\mathrm{Fe}^{2+}\right)$ & $(\mathrm{mg} / \mathrm{L})$ & 0.03 & 0.02 & 0.14 & 0.16 & 0.13 & 0.08 & 0.15 & 0.08 & ND & 0.03 & 0.05 & ND & 0.17 & 0.04 & 0.19 & 0.20 & ND & 0.21 & 0.19 & 0.02 \\
\hline Sodium $\left(\mathrm{Na}^{+}\right)$ & $(\mathrm{mg} / \mathrm{L})$ & 50.00 & 45.00 & 83.00 & 73.00 & 18.60 & 38.66 & 40.59 & 68.00 & 82.70 & 75.60 & 90.00 & 36.00 & 54.70 & 79.99 & 48.68 & 30.55 & 48.32 & 50.25 & 48.99 & 56.78 \\
\hline $\begin{array}{l}\text { Bicarbonates } \\
\left(\mathrm{HCO}_{3}\right)\end{array}$ & $(\mathrm{mg} / \mathrm{L})$ & 87.00 & 86.70 & 57.60 & 43.90 & 56.70 & 46.50 & 32.80 & 41.30 & 60.00 & 61.40 & 78.80 & 48.50 & 28.60 & 50.30 & 48.50 & 56.00 & 28.60 & 48.69 & 87.50 & 75.00 \\
\hline Calcium $\left(\mathrm{Ca}^{2+}\right)$ & $(\mathrm{mg} / \mathrm{L})$ & 36.60 & 37.70 & 32.50 & 16.80 & 16.87 & 8.70 & 9.80 & 31.50 & 9.80 & 7.70 & 6.70 & 8.90 & 17.80 & 16.70 & 15.50 & 40.50 & 30.00 & 9.20 & 8.80 & 7.90 \\
\hline $\begin{array}{l}\text { Magnesium } \\
\left(\mathrm{Mg}^{2+}\right)\end{array}$ & $(\mathrm{mg} / \mathrm{L})$ & 8.30 & 3.80 & 3.90 & 5.90 & 7.40 & 5.90 & 4.10 & 8.00 & 9.00 & 6.70 & 6.80 & 4.10 & 4.00 & 2.80 & 2.90 & 2.70 & 3.80 & 3.70 & 2.20 & 2.00 \\
\hline $\begin{array}{l}\text { Total Dissolved } \\
\text { solid }\end{array}$ & $(\mathrm{mg} / \mathrm{L})$ & 112.4 & 43.10 & 22.00 & 17.50 & 23.00 & 17.10 & 12.80 & 33.90 & 10.60 & 14.60 & 55.00 & 32.00 & 32.50 & 50.60 & 70.50 & 80.80 & 90.00 & 100.0 & 60.00 & 55.50 \\
\hline $\begin{array}{l}\text { Total Suspended } \\
\text { solids }\end{array}$ & $(\mathrm{mg} / \mathrm{L})$ & 31.24 & 12.82 & 32.71 & 11.92 & 31.72 & 18.70 & 75.40 & 66.00 & 19.80 & 20.00 & 23.00 & 23.10 & 34.60 & 35.70 & 13.50 & 14.60 & 18.24 & 70.80 & 80.70 & 90.60 \\
\hline Total & $\mathrm{Cfu} / 0 \mathrm{ml}$ & 24 & 16 & 20 & 15 & 20 & 20 & 19 & 28 & 27 & 20 & 18 & 40 & 50 & 40 & 50 & 60 & 70 & 52 & 45 & 27 \\
\hline E-coli & $\mathrm{Cfu} / 100 \mathrm{ml}$ & 0 & 0 & 0 & 0 & 1 & 1 & 1 & 1 & 1 & 1 & 1 & 0 & 0 & 0 & 0 & 0 & 0 & 1 & 1 & 0 \\
\hline
\end{tabular}


which is for drinking water, which is indicative of relatively low electrical conductivity or dissolved ions.

\subsection{Temperature (Kelvin)}

The temperatures in the well water samples are uniform and are found to vary between $28 \& 30$. The condition of the well also have some influence e.g. well depth, whether it is covered or not nature of material used for the cover etc.

\subsubsection{Color (APHA)}

From visual observation, most of the samples appeared clear or colorless. A few obtained from areas of shallow water Table showed brownish coloration suspected to be due to presence of organic matter. The algae infested sample from well 1 was typically light green in colour.

\subsubsection{Odor and taste}

The well water samples collected were subjected to mammal sensation. All the samples were found not to be objectionable to man.

\subsubsection{Total suspended solids (TSS) $(\mathrm{mg} / \mathrm{l})$}

Solid matter or residue suspended in water may affect its quality adversely in a number of ways. Water with high residues is less acceptable to consumer for domestic or industrial purpose as it might induce unfavorable physiological reactions. According to Ademoroti [11], the amount of suspended solid in water can vary widely, depending upon flow, sensation and handling.The amounts of suspended soil in all the well water samples vary from $10-20 \mathrm{ppm}$. This value is very low compared to the WHO permissible range for suspended solids which is about $500 \mathrm{ppm}$. This may be as a result of the filtration capacity of the weathered materials overlying the bedrocks in the study area.

\subsubsection{Total dissolved solid (TDS) $(\mathrm{mg} / \mathrm{L})$}

The total dissolved solid content (TDS) is also known as the total salt concentration of groundwater.Groundwater can be classified according to its TDS content. Hem [12] classified water sample on the basis of TDS as stated below.

The TDS concentration for all the well water samples tested varies from $132-1320.00 \mathrm{ppm}$ and therefore classify as fresh water. They also fall below the WHO [13] desirable limit for drinking water. The TDS concentration for all the water samples tested are not objectionable, the low maximum limit in the area is due to the very minute concentration of salt around Ososo town. That means 99\% of the samples fall under fresh groundwater based on WHO desirable maximum limit for TDS which is $1000 \mathrm{ppm}$ but are above UNIBEN water.

\subsubsection{Total hardness}

The hardness of water relate to its reaction with soup and to the scale and incrustation accumulating in containers or conduits where water is heated. The WHO recommended standard for drinking water is $500 \mathrm{ppm}$. All the samples tested have hardness which falls below the WHO standard. Over $90 \%$ of the samples tested possess carbonate and magnesium sulphate hardness.

Hem [12] classified water according to its hardness as follows

Based on the classification above, one of the samples tested is grouped as soft, while nine (9) of the rest samples were moderately hard. Generally the well water sample varied from $(25-95 \mathrm{ppm})$ i.e. soft to moderately hard as was similarly observed at Akure by Emofurieta et al. [14]. Some amount of magnesium sulphate $\left(\mathrm{MgSO}_{4}\right)$ hardness is suspected due to the influence of silicate minerals in the basement rocks.

\subsubsection{Total alkalinity}

The phenolphthalein value for the sample tested was zero. This implied that both carbonate and hydroxide alkalinities were absent in the samples. The alkalinities present were due to the bicarbonate ions. This is indicated by the $\mathrm{pH}$ values, which are less than 7.5. The alkalinity values vary between 3.0 to $18.0 \mathrm{ppm}$. The WHO [15] recommended standard for alkalinity is below $200 \mathrm{ppm}$. All the well water samples have below $200 \mathrm{ppm}$. This shows that the samples are slightly acidic in nature. The dissolved carbonate concentrations were obtained by calculation from the total alkalinity.

\subsection{Biological Analysis Results}

Bacteriological analysis is important for detecting biological pollution of groundwater. However because of the difficulty in isolating pathogenic bacteria found in water, in the laboratory standard test to determine their presence or absence in water sample are based on the relatively ease to isolate and identify bacteria of the coliform group (e.g. fecal Coliform and E.coli) as a direct indication of the safety of the water for drinking purposes. The bacterial loads in the hand-dug wells water samples are shown in Table 5.

\subsection{Chemical Analysis Results}

\subsubsection{The cations}

Calcium (ca): This was one of the most abundant Cat ions in the entire well water sample tested with concentration varying from $6.4-$ $40.0 \mathrm{mg} / \mathrm{L}$. All the samples tested have less than $100 \mathrm{ppm}$. Generally, the maximum limit of WHO is $200 \mathrm{mg} / \mathrm{L}$. The presence of calcium in water has effect on uses of the water. Calcium generally combines with bicarbonate, carbonate, sulphur and silica to form heat retarding, pipe clogging, scales in boilers and other heat exchange equipment. Calcium combines with ions of fatty acid to form soap subs.

Magnesium (Mg):Magnesium concentration in the well water sample vary from $2.0-9.5 \mathrm{ppm}$ as compared to the accepted maximum of WHO standard of $20 \mathrm{mg} / \mathrm{L}$. The major sources of magnesium in water are from igneous rocks and dolomite. High concentration of magnesium has a laxative effect [16]. 
Table 2: Results of heavy mineral analysis.

\begin{tabular}{|c|c|c|c|c|c|c|c|c|c|}
\hline Sample & $\mathrm{Cu}(\mathrm{mg} / \mathrm{L})$ & $\mathrm{Pb}(\mathrm{mg} / \mathrm{L})$ & $\operatorname{Zn}(\mathbf{m g} / \mathbf{L})$ & $\mathbf{K}(\mathbf{m g} / \mathbf{L})$ & $\mathrm{V}(\mathrm{mg} / \mathrm{L})$ & $\operatorname{Cd}(\mathrm{mg} / \mathrm{L})$ & $\mathbf{C r}(\mathbf{m g} / \mathbf{L})$ & $\mathrm{Ni}(\mathrm{mg} / \mathrm{L})$ & $\mathbf{B a}(\mathbf{m g} / \mathbf{L})$ \\
\hline Well-1 & 0.4 & 0.1 & 13.4 & 50.6 & 0.1 & 0.1 & 0.8 & 0.2 & 0.5 \\
\hline Well-2 & 0.4 & 0.1 & 12.3 & 55.8 & 0.1 & 0.1 & 0.6 & 0.2 & 0.5 \\
\hline Well-3 & 0.4 & 0.2 & 11.3 & 60.4 & 0.1 & 0.1 & 0.9 & 0.2 & 0.4 \\
\hline Well-4 & 0.3 & 0.2 & 6.1 & 66.7 & 0.1 & - & 0.7 & 0.1 & 0.4 \\
\hline Well-5 & 0.3 & 0.1 & 5.1 & 90.5 & & - & 0.5 & 0.1 & 0.5 \\
\hline Well-6 & 0.3 & - & 4.2 & 80.5 & 0.1 & - & 0.3 & 0.1 & 0.5 \\
\hline Well-7 & 0.2 & - & 5.6 & 97.4 & 0.1 & 0.1 & 0.2 & - & 0.04 \\
\hline Well-8 & 0.4 & 0.2 & 4.0 & 96.6 & 0.1 & 0.1 & 0.3 & - & 0.04 \\
\hline Well-9 & 0.2 & 0.2 & 4.6 & 100.0 & - & 0.1 & 0.4 & - & 0.2 \\
\hline Well-10 & 0.2 & 0.1 & 9.6 & 135.2 & - & - & 0.4 & 0.2 & 0.3 \\
\hline Well-11 & 0.1 & 0.1 & 7.8 & 140.4 & - & - & 0.5 & 0.3 & 0.4 \\
\hline Well-12 & 0.1 & 0.1 & 6.9 & 112.8 & - & - & 0.5 & 0.3 & 0.4 \\
\hline Well-13 & 0.2 & - & 0.8 & 132.3 & 0.1 & - & 0.6 & 0.1 & 0.3 \\
\hline Well-14 & 0.2 & - & 5.2 & 114.4 & & 0.1 & 0.7 & 0.1 & 0.3 \\
\hline Well-15 & 0.3 & 0.2 & 5.0 & 125.6 & 0.1 & 0.1 & 0.2 & 0.1 & 0.5 \\
\hline Well-16 & 0.3 & 0.2 & 4.5 & 112.0 & 0.1 & 0.1 & 0.6 & 0.2 & 0.5 \\
\hline Well-17 & 0.4 & 0.1 & 4.3 & 112.0 & & 0.003 & 0.03 & 0.2 & 0.05 \\
\hline Well-18 & 0.4 & 0.01 & 8.5 & 110.5 & - & 0.003 & 0.05 & 0.2 & 0.05 \\
\hline Well-19 & 0.4 & 0.01 & 6.6 & 110.5 & 0.1 & 0.1 & 0.05 & 0.3 & 0.5 \\
\hline UNIBEN 0.1 & 0.01 & 5.0 & 115.6 & 0.1 & 0.1 & 0.03 & 0.3 & 0.4 & \\
\hline
\end{tabular}

Table 3: Showing HEM [12] Classification of Total Dissolved Solid.

\begin{tabular}{ll}
\hline Fresh & $<1000 \mathrm{ppm}$ \\
Moderately saline & $3000-10000 \mathrm{ppm}$ \\
Very saline & $10000-35000 \mathrm{ppm}$ \\
Brine & $>35000 \mathrm{ppm}$ \\
\hline
\end{tabular}

Table 4: Showing HEM [12] Classification of Total Hardness.

\begin{tabular}{ll}
\hline Hardness (PPM CaCO & Class \\
\hline Soft & $00-60$ \\
Moderately & $61-120$ \\
Hard & $121-180$ \\
Very hard & $>180$ \\
\hline
\end{tabular}

Table 5: Bacteria Load (Cfu/100 ml) in shallow handdug wells in Ososo.

\begin{tabular}{lc}
\hline Sample No. & Bacterial load $(\mathbf{c f u} / \mathbf{1 0 0 m l})$ \\
\hline 1 & $3.4 \times 10^{2}$ \\
2 & $1.5 \times 10^{2}$ \\
3 & $0.3 \times 10^{2}$ \\
4 & $0.8 \times 10^{2}$ \\
5 & $1.0 \times 10^{2}$ \\
6 & $2.0 \times 10^{2}$ \\
7 & $0.2 \times 10^{2}$ \\
8 & $1.8 \times 10^{2}$ \\
9 & $0.9 \times 10^{2}$ \\
10 & $0.6 \times 10^{2}$ \\
\hline
\end{tabular}

Sodium(Na): The dissolved sodium content values vary from $17.9-92.5 \mathrm{mg} / \mathrm{L}$. the major sources of sodium are from feldspar (albite), clay minerals, evaporates and industrial wastes. The WHO standard for sodium in drinking water is $200 \mathrm{mg} / \mathrm{L}$. All the water samples tested gave sodium value below $100 \mathrm{mg} / \mathrm{L}$. When sodium is greater than $50 \mathrm{mg} / \mathrm{l}$ in the presence of suspended matters, it causes foaming which accelerates scale formation and corrosion in boilers [16]. The major source of sodium is from feldspar (albite), clay minerals, evaporate and industrial waste.

\subsubsection{The anions}

\section{Sulphate $\left(\mathbf{S O}_{4}^{2-}\right)$}

The concentration of sulphate ions vary from 93$125 \mathrm{mg} / \mathrm{L}$ which fell below $250 \mathrm{mg} / \mathrm{L}$ for the maximum permissible limit of WHO. Sulphate combines with calcium to form an adherent heat retarding scale. High concentration of sulphate gives bitter taste to water, and can produce laxative infects in human. It causes permanent hardness in water through the formation of magnesium sulphate. Sulphate is formed from the oxidation of pyrite and other sulphate widely distributed in igneous and sedimentary rocks.

Bicarbonate $\left(\mathrm{CO}_{3}\right)$

The bicarbonate concentrations in all the well water samples vary from $25.7-90 \mathrm{mg} / \mathrm{L}$ which are relatively below $200 \mathrm{mg} / \mathrm{l}$ of the WHO permissible limit. The major sources are from limestone and dolomite. When heated, bicarbonate is changed into steam, $\mathrm{CO}_{2}$ and $\mathrm{CO}_{3}$. The carbonate combines with alkaline earth metals especially $\mathrm{Ca}$ and $\mathrm{Mg}$ to form a crust-like scale of $\mathrm{CaCO}_{3}$ that retards flow of heat through pipes. The major sources are limestone, dolomite less than $50 \mathrm{mg} / \mathrm{L}$ in water.

Nitrates and nitrites: Nitrates and nitrites are produced naturally as part of the nitrogen cycle, when a bacteria production line breaks down toxic ammonia waste first into nitrites and then into 
Table 6: Physical characteristics of standards. Water quality criteria (SON [17] AND WHO [15]) standards. WHO, [15].

\begin{tabular}{|c|c|c|c|c|}
\hline \multirow[t]{2}{*}{ S/No. } & \multirow[t]{2}{*}{ Parameter } & \multirow[t]{2}{*}{ SON Standard } & \multicolumn{2}{|c|}{ WHO Standard } \\
\hline & & & Highest Desirable & Maximum Permissible \\
\hline 1 & Colour & $3.0 \mathrm{TCU}$ & $3.0 \mathrm{TCU}$ & $15.0 \mathrm{TCU}$ \\
\hline 2 & Odour & NS & NS & NS \\
\hline 3 & Taste & NS & NS & NS \\
\hline 4 & $\mathrm{PH}$ at $20^{\circ} \mathrm{C}$ & $6.50-8.50$ & $7.0-8.9$ & $6.90-9.50$ \\
\hline 5 & Turbidity & $5.0 \mathrm{NTU}$ & $5.0 \mathrm{NTU}$ & $5.0 \mathrm{NTU}$ \\
\hline 6 & Conductivity & $1000(\mu \mathrm{S} / \mathrm{cm})$ & $100(\mu \mathrm{S} / \mathrm{cm})$ & $1200(\mu \mathrm{S} / \mathrm{cm})$ \\
\hline 7 & Total Solid & $500 \mathrm{mg} / \mathrm{L}$ & $500 \mathrm{mg} / \mathrm{L}$ & $1500 \mathrm{mg} / \mathrm{L}$ \\
\hline 8 & Total Alkalinity & $100 \mathrm{mg} / \mathrm{L}$ & $100 \mathrm{mg} / \mathrm{L}$ & $100 \mathrm{mg} / \mathrm{L}$ \\
\hline 9 & Phenolphthalein Alkalinity & $100 \mathrm{mg} / \mathrm{L}$ & $100 \mathrm{mg} / \mathrm{L}$ & $100 \mathrm{mg} / \mathrm{L}$ \\
\hline 10 & Chloride & $100 \mathrm{mg} / \mathrm{L}$ & $200 \mathrm{mg} / \mathrm{L}$ & $250 \mathrm{mg} / \mathrm{L}$ \\
\hline 11 & Fluoride & $1.0 \mathrm{mg} / \mathrm{L}$ & $1.0 \mathrm{mg} / \mathrm{L}$ & $1.5 \mathrm{mg} / \mathrm{L}$ \\
\hline 12 & Copper & $1.0 \mathrm{mg} / \mathrm{L}$ & $0.5 \mathrm{mg} / \mathrm{L}$ & $2.0 \mathrm{mg} / \mathrm{L}$ \\
\hline 13 & Iron & $0.3 \mathrm{mg} / \mathrm{L}$ & $0.3 \mathrm{mg} / \mathrm{L}$ & $1.0 \mathrm{mg} / \mathrm{L}$ \\
\hline 14 & Nitrate $\left(\mathrm{NO}_{3}\right)$ & $10 \mathrm{mg} / \mathrm{L}$ & $10 \mathrm{mg} / \mathrm{L}$ & $50 \mathrm{mg} / \mathrm{L}$ \\
\hline 15 & Nitrite $\left(\mathrm{NO}_{2}\right)$ & $0.02 \mathrm{mg} / \mathrm{L}$ & $0.2 \mathrm{mg} / \mathrm{L}$ & $3 \mathrm{mg} / \mathrm{L}$ \\
\hline 16 & Manganese & $0.05 \mathrm{mg} / \mathrm{L}$ & $0.1 \mathrm{mg} / \mathrm{L}$ & $0.1 \mathrm{mg} / \mathrm{L}$ \\
\hline 17 & Magnesium & $0.20 \mathrm{mg} / \mathrm{L}$ & $20 \mathrm{mg} / \mathrm{L}$ & $20 \mathrm{mg} / \mathrm{L}$ \\
\hline 18 & Zinc & $5.0 \mathrm{mg} / \mathrm{L}$ & $0.01 \mathrm{mg} / \mathrm{L}$ & $0.01 \mathrm{mg} / \mathrm{L}$ \\
\hline 19 & Selenium & NS & $0.01 \mathrm{mg} / \mathrm{L}$ & $0.01 \mathrm{mg} / \mathrm{L}$ \\
\hline 20 & Silver & - & NS & NS \\
\hline 21 & Cyanide & $0.01 \mathrm{mg} / \mathrm{L}$ & $0.01 \mathrm{mg} / \mathrm{L}$ & $0.07 \mathrm{mg} / \mathrm{L}$ \\
\hline 22 & Sulphate & $100 \mathrm{mg} / \mathrm{L}$ & $250 \mathrm{mg} / \mathrm{L}$ & $500 \mathrm{mg} / \mathrm{L}$ \\
\hline 23 & Calcium & $75 \mathrm{mg} / \mathrm{L}$ & NS & NS \\
\hline 24 & Aluminum & NS & $0.2 \mathrm{mg} / \mathrm{L}$ & $0.2 \mathrm{mg} / \mathrm{L}$ \\
\hline 25 & Potassium & $10.0 \mathrm{mg} / \mathrm{L} \mathrm{NS}$ & NS & \\
\hline 26 & Lead & $0.01 \mathrm{mg} / \mathrm{L}$ & $0.01 \mathrm{mg} / \mathrm{L}$ & $0.01 \mathrm{mg} / \mathrm{L}$ \\
\hline 27 & Chromium & $0.05 \mathrm{mg} / \mathrm{L}$ & $0.05 \mathrm{mg} / \mathrm{L}$ & $0.05 \mathrm{mg} / \mathrm{L}$ \\
\hline 28 & Cadmium & $0.003 \mathrm{mg} / \mathrm{L}$ & $0.003 \mathrm{mg} / \mathrm{L}$ & $0.003 \mathrm{mg} / \mathrm{L}$ \\
\hline 29 & Arsenic & $0.01 \mathrm{mg} / \mathrm{L}$ & $0.01 \mathrm{mg} / \mathrm{L}$ & $0.01 \mathrm{mg} / \mathrm{L}$ \\
\hline 30 & Barium & $0.05 \mathrm{mg} / \mathrm{L}$ & $0.05 \mathrm{mg} / \mathrm{L}$ & $0.07 \mathrm{mg} / \mathrm{L}$ \\
\hline 31 & Mercury & $0.001 \mathrm{mg} / \mathrm{L}$ & $0.001 \mathrm{mg} / \mathrm{L}$ & $0.002 \mathrm{mg} / \mathrm{L}$ \\
\hline 32 & Antimony & NS & - & $0.02 \mathrm{mg} / \mathrm{L}$ \\
\hline 33 & Tin & - & - & $0.02 \mu \mathrm{g} / \mathrm{L}$ \\
\hline 34 & Nickel & - & - & $0.02 \mathrm{mg} / \mathrm{L}$ \\
\hline 35 & Total Hardness $\left(\mathrm{CaCO}_{3}\right)$ & $100 \mathrm{mg} / \mathrm{L}$ & $100 \mathrm{mg} / \mathrm{L}$ & $500 \mathrm{mg} / \mathrm{L}$ \\
\hline 36 & Vinyl chloride & $0 \mathrm{mg} / \mathrm{L}$ & $0 \mathrm{mg} / \mathrm{L}$ & $0 \mathrm{mg} / \mathrm{L}$ \\
\hline
\end{tabular}

Table 7: Water quality criteria ([14]) standards.

\begin{tabular}{llll}
\hline S/No. & Substances & Permissible & Excessive \\
\hline 1 & Total solids & $500 \mathrm{ppm}$ & $1,500 \mathrm{ppm}$ \\
2 & Colour & 5 Unit (pt-co scale) & $50 \mathrm{units}$ \\
3 & Taste & Unobjectionable & \\
4 & Turbidity & 5 units & 25 units \\
5 & Odour & Unobjectionable & \\
6 & Iron(Fe) & $0.3 \mathrm{ppm}$ & $1.0 \mathrm{ppm}$ \\
7 & Manganese(Mn) & $0.1 \mathrm{ppm}$ & $0.5 \mathrm{ppm}$ \\
8 & Lead(Pb) & $0.05 \mathrm{ppm}$ & \\
9 & Copper(Cu) & $1.0 \mathrm{ppm}$ & $1.5 \mathrm{ppm}$ \\
10 & Zinc(Zn) & $5.0 \mathrm{ppm}$ & $200 \mathrm{ppm}$ \\
11 & Calcium(Ca) & $75 \mathrm{ppm}$ & $150 \mathrm{ppm}$ \\
12 & Magnesium(Mg) & $50 \mathrm{ppm}$ & $400 \mathrm{ppm}$ \\
13 & Sulphate(SO & $600 \mathrm{ppm}$ \\
14 & Chloride(Cl) & $200 \mathrm{ppm}$ & \\
15 & pH range & $200 \mathrm{ppm}$ & $1000 \mathrm{ppm}$ \\
16 & Sulphate $(\mathrm{Mg}+\mathrm{Na})$ & $6.0-8.5$ & $0.002 \mathrm{ppm}$ \\
17 & Phenolic Substance (As phenol) & $500 \mathrm{ppm}$ & $0.001 \mathrm{ppm}$ \\
\hline
\end{tabular}


nitrates. These bacteria are called nitrogen fixing bacteria e.g. nitrosomonas and nitrobacteria. Upon the death and decay of the plants and bacteria, the nitrates are being leached from the topsoil into groundwater by infiltration water [16]. The dissolved nitrates concentrations vary from 5.7 - 9.1 the maximum desirable WHO [15] limit for nitrates and nitrites is $10 \mathrm{mg} / \mathrm{l}$ all the well water sampled tested gave values below this limit. Nitrates also gets in the waterways from lawn fertilizer runoff, leaking septic tanks, animal waste and effusion from car exhaust. Nitrates stimulate the growth of planktons and water weeds that provide food for fishes. However, if algae grow too widely, oxygen levels would be reduced and the fishes would die. A higher concentration of nitrate in drinking water is harmful for infants as a result of blue baby disease. Because infants lack sufficient acidity, nitrate reducing bacteria can grow in their upper intestinal tracts. Samples with relatively high nitrite contents also contain significantly high nitrate concentrations. This association maybe as a result of pollution by sewage still undergoing nitrification.

\subsection{Heavy Metals}

\subsubsection{Copper (Cu)}

The concentrations of copper in the samples analyzed shows values ranging from $0.1-0.5$ the values fell below the WHO permissible limit of $0.5 \mathrm{mg} / \mathrm{l}$. In the situation where the standard is exceeded, it can result in stomach and intestinal disorder, liver, damage and anemia.

\subsubsection{Lead $(\mathrm{Pb})$}

The result of the analysis indicates high values of lead in nine samples and was not detected in wells 6 and 7. The values for other wells ranged between $0.1-0.2 \mathrm{mg} / \mathrm{l}$ as against the WHO standard which is 0.01 . The effect of the high concentration of lead, as analyzed from these sample will be, affecting red blood cell chemistry, delay in normal physical growth in children and can also cause slight increase in blood pressure in some adults.

\subsubsection{Chromium $(\mathrm{Cr})$}

From the analysis the values, the values for the concentration of chromium in the water samples from the wells ranges from $0.4-0.89 \mathrm{mg} / \mathrm{l}$, which exceeds the WHO standard of $0.005 \mathrm{mg} / 1$ wells 4 and 5 correlated with WHO standard The likely source of chromium in groundwater include run-off from abandoned mining operations, fossil fuel combustion and waste incineration. The consequences of over concentration of chromium in drinking water include liver and kidney damage, respiratory damage and internal hemorrhage.

\subsubsection{Barium ( $\mathrm{Ba})$}

The values of barium analyzed ranged from $0.05-0.3 \mathrm{mg} / \mathrm{l}$, the values exceeded the WHO standard of 0.7 thus making the water useful for consumption. High concentration of barium causes a variety of cardiac, gastro-intestinal and neuromuscular effect associated with hypertension.

\subsubsection{Cadmium (Cd)}

limit for Cadmium $0.003 \mathrm{mg} / \mathrm{l}$ in water. Result from the heavy mineral analysis gave an approximate value of 0.2 and below detectable limit in the other wells. For the wells that Cadmium was detected they obviously exceeded the standard and this alteration could cause serious health challenges if not checked. Over concentration of cadmium in water causes high blood pressure, destroys testicular tissue and red blood cells. It also becomes toxic to aquatic biota.

\subsubsection{Zinc (Zn)}

The values of zinc in the samples analyses exceeded the permissible limit of WHO which is $0.01 \mathrm{mg} / \mathrm{l}$, they ranged from $0.8-11.4$. The high concentration of zinc can be attributed to run-off from industrial waste and most times occurring naturally in groundwater. The presence of zinc aids in the healing of wounds and generally causes no ill effect. However excess of it gives taste to water and also becomes toxic to plants.

\subsubsection{Nickel (Ni)}

The values of nickel range from 0.1$0.5 \mathrm{mg} / \mathrm{l}$.WHO maximum permissible limit for nickel in groundwater is $0.02 \mathrm{mg} / \mathrm{l}$. Comparing values from the analysis with WHO standard shows clearly that the range of values from the analysis exceed the WHO standard limit, thus making the water unsafe for human consumption. The effects resulting from high concentration of nickel in water include damages to heart and liver.

CFU means colony forming unit.

\section{CONCLUSION}

Highly populated areas have groundwater with high concentrations of dissolved ions and the reverse for low populated areas in the study area. The total dissolved solid content (TDS) concentration for all the samples varies from 132 $1320.00 \mathrm{ppm}$.It is safe to conclude that the groundwater chemistry has been more influenced by human activities rather than the bed rock geology.

\section{ACKNOWLEDGEMENT}

Authors are grateful to the Ososo Community for their kindness in granting us access to their hand dug wells.

\section{References}

[1] M. John, "Groundwater Chemistry of Weathered Zone Aquifer on an area underlain by basement complex rocks," Journal of Africa Earth sciences, pp. 357-371, 1996.

[2] T. Onyeobi and C. Akujieze, "Characterization of Soil and Sediment Parameters of Jisike-Izombe Upper Aquifer System for Assessment of Potential of Groundwater Pollution," J. Appl. Sci. Environ. Management, vol. 18 , no. 4 , pp. $674-683,2014$.

[3] A. I. A., "Aspect of the hydrology of the western Niger Delta wetlands: groundwater conditions in the Neogene deposits of the Ndokwa Area," Africa Geosciences Review, vol. 18, no. 3, pp. 25-35, 2011.

[4] G. Oteze, "Water supply, groundwater and flood control in benin," presented at the NMGS, Benin chapter Sensitization workshop on water resources management and its implications in Benin City, 22nd March, 2011. 
[5] M. Isikhuemen and O. Omorogieva, "Hydrogeochemical and Biophysical Characterization of Groundwater in Eastern Nigeria; A Case Study of Onitsha and Environ." Nigeria Journal of Technology, vol. 34, no. 4, pp. 875-882, 2015.

[6] P. Coorey, "Some aspects of the Precambrian of Nigeria: A review," J. Min. Geol., vol. 8, pp. 17-43, 1974.

[7] M. Rahaman, "Review of the basement geology of south western nigeria," in •, C. Kogbe, Ed., Geology of Nigeria. Elizabethan Pub. Co., 1976, pp. 41-58.

[8] I. Oloto and D. Anyanwu, "Petrology of Ibillo-Mangongo area of Igarra, Edo State, Nigeria,"Adv. Appl. Sci. Res., vol. 4, no. 3, pp. 140-145, 2013.

[9] S. Watt and W. Wood, "Hand dug wells and their construction," Intermediate Technology Publications, vol. $234,1977$.

[10] Malomoet, "Ground water chemistry of weathered zone aquifers underlain by basement complex rocks," Journal of African Earth Sciences, vol. 11, no. 3, pp. 357371, 1990.

[11] C. Ademoroti, Environmental Chemistry and toxicology, 1st ed. Ibadan: Folutex Press Limited, 1996.

[12] J. Hem, Interpretation of the Chemical Characteristic of Natural Water. 3rd: Geological Survey Water Supply, 1970.

[13] WHO, "On water quality adapted from health canada's social media tools," modified 21-12-2010, 2010.

[14] W. O. Emofurieta, "A paper presented on quality of groundwater in akure metropolis, ondo state," FEPA, Guidelines and Standards for Environment Pollution Control in Nigeria. Federal environmental protection agency, Federal Republic of Nigeria., 1991.

[15] wHO, "Guidelines for drinking-water quality," Chapter 9: Radiological Aspect, 2011.

[16] C. Durfer and F. Baker, "Public water supplies of the 10 larger cities in the U.S. Geological Survey," Water Supply, vol. 1812 , no. $364,1964$.

[17] SON, "Nigerian standard for drinking water quality," The Standards Organization of Nigeria (SON), Lagos, Nigeria, pp. 15-19, 2007. 